ОТ «МУЖЕСТВА НАДЕЖДЫ» К ФИЛОСОФСКОЙ ВЕРЕ Рецензия на книгу: A World Beyond Global Disorder. A Courage of Hope / ed. by E. Demenchonok, F. Dallmayr. - Cambridge Scholars

Publishing: Newcastle upon Tyne, 2017. -360 p.

(Мир по ту сторону глобального беспорядка: мужество надежды / под ред. Э. Деменчонка и Ф. Даллмайра. - Ньюкасл на Тайне (Великобритания): Кембриджское научное издательство, 2017. - 360 с.)

\title{
C.В. АКОПОВ
}

Начиональный исследовательский университет «Выстая школа экономики», Санкт-Петербург, Россия

Акопов Сергей Владимирович - доктор политических наук, профессор департамента политологии Национального исследовательского университета «Высшая школа экономики».

sakopov@hse.ru

Цитирование: $A К О П О В$ C.B. (2018) От «мужества надежды» к философской вере. Рецензия на книгу: A World Beyond Global Disorder. A Courage of Hope / ed. by E. Demenchonok, F. Dallmayr. - Cambridge Scholars Publishing: Newcastle upon Tyne, 2017. 360 p. // Философские науки. 2017. № 3. С. 154-159.

DOI: $10.30727 / 0235-1188-2018-3-154-159$.

Замысел рецензируемой коллективной монографии состоит в феноменологическом исследовании «глобального беспорядка» однополярного мира, рассматриваемого в первой части монографии, и в последующем переходе к обсуждению стратегии его преодоления во второй части. В заключительной, третьей части книги авторы рассматривают религиозные, духовные и этические ресурсы для создания мирного и справедливого космополитичного миропорядка.

Книга открывается эпиграфом отражающим, возможно, главный посыл редакторов монографии: «Say a prayer for Paris by all means, but pray more, for the world that doesn't have a prayer for those who no longer have a home to defend. For the world that is falling apart in all corners, and not simply in the towers and cafes we find so familiar»*. Этот посыл заключается в необходимости перехода от одномерного монологичного мира (культурных) стереотипов и авторитарных (политических) указаний к открытому плюралистичному диалогическому миру культурно-исторического со-творчества свободных личностей. При этом гегемонии однополярного мира, прежде всего США (с. 196-198), авторы противопоставляют проекты альтернативного миропорядка, основанного на идее равноправного диалога и сотрудничества людей, представляющих различные культурные традиции. Это является необходимым условием сотрудничества по решению или хотя бы смягче-

* «Произнесите молитву о Париже во что бы то ни стало, но еще больше молитесь за мир, в котором нет молитвы. Молитесь за тех, у кого больше нет дома, который им можно было бы защищать. Молитесь за мир, который разваливается повсюду, а не просто в башнях или в кафе, которые мы находим для себя столь знакомыми». 


\section{С.В. АКОПОВ. От «мужества надежды» к философской вере. Рецензия на книгу...}

нию глобальных проблем (ядерных вооружений, бедности, изменения климата), от чего зависит будущее человечества.

В духе завета П. Тиллиха, авторы книги противопоставляют безнадежности глобального беспорядка смелость сохранять в себе надежду на ее изменение. Не случайно, видимо, само название книги «Мужество надежды» под редакцией Эдуарда Деменчонка и Фреда Даллмайра перекликается с книгой известного лингвиста и философа Ноама Чомского «Оптимизм вместо безнадежности: о капитализме, империи и социальных переменах» (Chomsky N. Optimism over Despair: On Capitalism, Empire, and Social Change. - Chicago: Hymarket, 2017). Одновременно с этим авторы книги выступают против детерминизма и обосновывают возможность перемен и необходимость перейти от ощущения безысходности гегемонистского мира к общепланетарной моральной соответственности (coresponsibility) и борьбе за свободное и достойное существование каждого человека.

Все отмеченные сюжеты проходят красной нитью и по-разному развиваются авторами глав монографии. Во введении, известный философ Фред Даллмайр (Fred Dallmayr, USA) в поисках философских оснований надежды обращается к наследию диалектической теологии П. Тиллиха и его Гарвардской речи 1965 г. «Право на надежду».

Первую часть книги, посвященную критике геополитической гегемонии, открывает глава Ричарда Фалька (Richard Falk, USA). Он обращает внимание читателя на конфликт между устарелой Вестфальской международной системой, традиционно базировавшейся на «жесткой силе» и гегемонизме, и нарождающейся новой геополитической парадигмой, ориентированной на «справедливость, самоопределение и этическое и экологическое сознание» (р. 22). Эти идеи развиваются в следующих главах. Акиль Бильграми (Akeel Bilgrami, India/USA) pacсматривает современный «глобальный беспорядок», преломляя его критику через противостояние «глобального севера» и «глобального юга». Он высказывает идею о необходимости ненасильственного сопротивления западному империализму. Вальтер Миньоло (Walter Mignolo, Argentina/USA) предлагает противопоставить существующей «колониальной матрице власти» идеи девестернизации и плюриверсальности. Даниэль Арчибуги (Daniel Archibugi, Italy) исследует феномен внесудебного убийства людей посредством дронов. Он видит в этом опасный триумф технологий над гуманизмом: «Мы убиваем, потому что можем убивать» (р. 64). Он считает это военным преступлением и предлагает учредить специальные суды общественного мнения (Public opinion tribunals), которые бы запретили убийства с помощью дронов. Аиис Нанди (Ashis Nandy, India) дает психологический (и даже психиатрический) диагноз таким явлениями современного мира как мания чрезмерного и беспорядочного насилия, например, в случае получения удовольствия от наблюдения за ковровыми бомбежками. Он предлагает активно бороться с подобной дегуманизацией современного общества, следуя примерам Нельсона Манделы и Далай-ламы (р. 74).

Вторая часть книги посвящена стратегиям противодействия и коррекции существующего «глобального беспорядка». Так, в своей главе Фабио Петито (Fabio Petito, Italy) уделяет значительное внимание корректировке логики «столкновения» цивилизаций в концепции С. Хантингтона. Вместо культурной замкнутости отдельных цивили- 
образования, усиление институтов региональной интеграции, развитие сотрудничества в рамках БРИКС и т.д.).

Следует отметить, что после прочтения книги начинаешь лучше понимать приведенный в ее начале эпиграф. Становится, например, более ясным, что первая часть эпиграфа может быть посвящена религиозной теме - теме веры и молитвы, как и собственно несколько глав сборника: «Произнесите молитву о Париже во что бы то ни стало, но еще больше молитесь за мир, в котором нет молитвы». Как видно из содержания книги, речь идет не только о христианской молитве, но и о духовности других конфессий. Вторая же часть эпиграфа призывает читателей молиться даже за незнакомый им мир. Так во фразе «молитесь за мир, который разваливается повсюду, а не просто в башнях или в кафе, которые мы находим для себя столь знакомыми» мы можем услышать не только отголоски террористических актов в «башнях-близнецах» 11 сентября 2001 г. в Нью-Йорке и в пяти парижских «кафе» 13 ноября 2015 г. Мы можем услышать и молитву за тех, кто погиб в Петербургском метро 4 апреля 2017 г. и за всех невинных жертв насилия. Также и текст самой книги побуждает читателя к сопереживанию авторам и к экзистенциальной транснациональной коммуникации с ними. Представляется, что и в самом замысле книги «Мир по ту сторону глобального беспорядка: мужество надежды», и в убежденности авторов в невозможности разрешения современных проблем в рамках только лишь одной страны, одной веры, одной философии (р. 227), а значит в необходимости гуманистического единения людей, можно увидеть развитие идеи «философской веры» немецкого философа Карла Ясперса. Это укрепляет надежду на лучшее будущее.

\section{FROM «A COURAGE OF HOPE» TOWARDS A PHILOSOPHICAL FAITH}
Book review: E. Demenchonok, F. Dallmayr (eds.) A World Beyond Global Disorder. A Courage of Hope. Cambridge Scholars Publishing: Newcastle upon Tyne, 2017. 360 p.

\section{S.V. AKOPOV}

National Research University Higher School of Economics, Saint Petersburg, Russia

Akopov, Sergei - D.Sc. in Political Science, Professor of the Department of Political Science at the National Research University Higher School of Economics Saint Petersburg.

sakopov@hse.ru

Citation: AKOPOV S.V. (2018) From "A Courage of Hope" towards a Philosophical Faith. Book Review: E. Demenchonok, F. Dallmayr (eds.). A World Beyond Global Disorder. A Courage of Hope. Cambridge Scholars Publishing: Newcastle upon Tyne, 2017. 360 p. In: Philosophical Sciences. 2018. Vol. 3, pp. 154-159.

DOI: $10.30727 / 0235-1188-2018-3-154-159$. 